\title{
Urinary bladder mass with emphysematous cystitis: double whammy
}

\author{
Kalpesh Mahesh Parmar, ${ }^{\ominus}$ Gopal Sharma, ${ }^{\ominus}$ Tushit Rai
}

Urology, Post Graduate Institute of Medical Education and Research, Chandigarh, India

Correspondence to Dr Kalpesh Mahesh Parmar, kalpesh010385@gmail.com

Accepted 21 May 2019

\section{DESCRIPTION}

A 46-year-old male patient presented with highgrade fever with chills of 3 days duration. Patient had severe dysuria and bothersome lower urinary tract symptoms like frequency, urgency and intermittency for the past 4 months. On further evaluation, patient had single episode of frank haematuria 1 year ago for which he did not take any advice. Patient consultated a general physician and was prescribed a course of oral antibiotics and antipyretics. He responded partially to medications and was referred to our institute. On examination, his resting pulse rate $112 / \mathrm{min}$ and temperature $39.8^{\circ} \mathrm{C}$. The rest of the physical examination was unremarkable. Systemic examination revealed a tense palpable mass present in the lower abdomen. The overlying skin and the rest of the systemic examination was normal. On digital rectal examination, prostate was grade 2, appeared benign and no supraprostatic mass was palpable. On evaluation, haemoglobin was $9.6 \mathrm{~g} / \mathrm{L}$, total leucocyte count was $16.2 \times 10^{9} / \mathrm{L}$, liver and renal function tests were normal. Urinalysis showed $30-40$ pus cells and culture

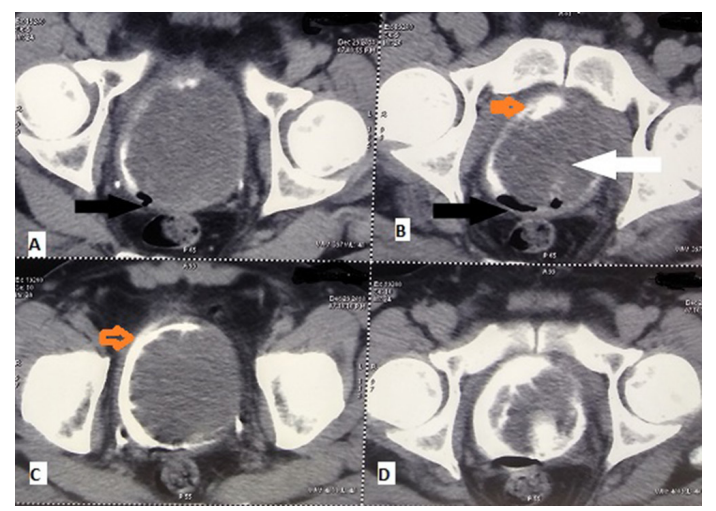

Figure 1 Contrast-enhanced CT images (axial images) $(A-D)$ showing large urinary bladder mass occupying the whole of urinary bladder (white solid arrow) and emphysematous cystitis (black solid arrow) and contrast filling the urinary bladder (solid orange arrow).

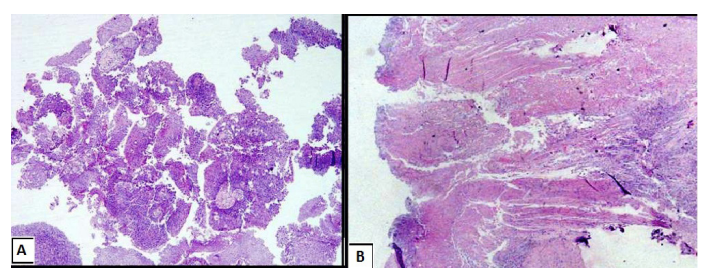

Figure 2 Histopathology of the transurethral resected bladder tumour chips (A) showing a tumour arranged in papillary configuration (H\&E stain, $\times 4$ ), and (B) detrusor muscle is involved by tumour.

\section{Patient's perspective}

I am very thankful to my team of doctors for managing my case so well.

\section{Learning points}

- Urinary bladder mass with emphysematous cystitis is extremely rare.

- Large bladder mass compressing the wall leads to necrosis and superimposed infection.

- Careful assessment and optimisation with broad-spectrum antibiotics is essential prior to transurethral resection of bladder tumour to prevent sepsis.

grew Escherichia coli for which sensitivity-based intravenous antibiotics was started. Ultrasound abdomen revealed solid appearing urinary bladder mass $5 \times 8 \mathrm{~cm}$ occupying the whole of the bladder with the presence of air specs. Bilateral kidneys were normal. CT urography revealed a bladder mass measuring $10 \times 6 \times 4 \mathrm{~cm}$ in size, and filling most of bladder lumen with intramural streak of gas was seen along the posterior wall of bladder (figures 1A-D; black solid arrow showing streak of gas and white solid arrow showing urinary bladder mass). Per urethral catheter, 16 French was placed in view of severe distress and gush of air, and frank pus was drained initially. Mild haematuria was present which got cleared later. After recovery, the patient underwent transurethral biopsy of the urinary bladder mass. Histopathology (H\&E stain) showed the presence of tumour arranged in nodules and cancer cells arranged in sheets, trabecular and fused papillae. There was increased mitosis, and tumour was seen infiltrating in between the muscularis propria (figure $2 \mathrm{~A}, \mathrm{~B}$ ). The patient is currently started on neoadjuvant chemotherapy.

Emphysematous cystitis is a rare entity seen mostly in diabetic and immunocompromised patients. ${ }^{12} \mathrm{CT}$ is gold standard with high sensitivity and specificity to detect gas in bladder wall and clinch the diagnosis. ${ }^{1}$ This case is peculiar as emphysematous cystitis in a patient with urinary bladder mass has not been reported as of this writing. Urinary bladder mass filling the whole of bladder compresses the bladder wall, leading to necrosis, and the superimposed infection seems to be the plausible cause for emphysematous cystitis.

Contributors TR and GS wrote the initial draft and collected data. GS edited the images. KMP did critical analysis. 


\section{Images in...}

Funding The authors have not declared a specific grant for this research from any funding agency in the public, commercial or not-for-profit sectors.

Competing interests None declared.

Patient consent for publication Obtained.

Provenance and peer review Not commissioned; externally peer reviewed.

\section{REFERENCES}

1 Thomas AA, Lane BR, Thomas AZ, et al. Emphysematous cystitis: a review of 135 cases. BJU Int 2007;100:17-20.

2 Kumar A, Turney JH, Brownjohn AM, et al. Unusual bacterial infections of the urinary tract in diabetic patients--rare but frequently lethal. Nephrol Dial Transplant 2001;16:1062-5.

Copyright 2019 BMJ Publishing Group. All rights reserved. For permission to reuse any of this content visit

https://www.bmj.com/company/products-services/rights-and-licensing/permissions/

BMJ Case Report Fellows may re-use this article for personal use and teaching without any further permission.

Become a Fellow of BMJ Case Reports today and you can:

- Submit as many cases as you like

Enjoy fast sympathetic peer review and rapid publication of accepted articles

- Access all the published articles

Re-use any of the published material for personal use and teaching without further permission

Customer Service

If you have any further queries about your subscription, please contact our customer services team on +44 (0) 2071111105 or via email at support@bmj.com.

Visit casereports.bmj.com for more articles like this and to become a Fellow 